九州大学学術情報リポジトリ

Kyushu University Institutional Repository

\title{
Full Factorial Experimental Design for Growth of Spirulina Platensis and Valuable Products
} Enhancement

Mir Shariful Islam

Mechanical Engineering Department, Kyushu University

Md. Matiar Rahman

Mechanical Engineering Department, Kyushu University

Bidyut Baran Saha

Mechanical Engineering Department, Kyushu University

https://doi.org/10.5109/4102506

出版情報: Proceedings of International Exchange and Innovation Conference on Engineering \& Sciences (IEICES). 6, pp. 299-304, 2020-10-22. Interdisciplinary Graduate School of Engineering Sciences, Kyushu University バージョン：

権利関係 : 


\title{
Full Factorial Experimental Design for Growth of Spirulina Platensis and Valuable Products Enhancement
}

\author{
Mir Shariful Islam ${ }^{1,2,3}$, Md. Matiar Rahman ${ }^{1,2}$, Bidyut Baran Saha ${ }^{1,2}$ \\ ${ }^{1}$ Mechanical Engineering Department, Kyushu University, 744 Motooka, Nishi-ku, Fukuoka 819-0395, Japan \\ ${ }^{2}$ International Institute for Carbon-Neutral Energy Research (WPI-I2CNER), Kyushu University, 744 Motooka, Nishi- \\ ku, Fukuoka 819-0395, Japan \\ ${ }^{3}$ Department of Oceanography, University of Dhaka, Dhaka-1000, Bangladesh \\ *Corresponding author email: saha.baran.bidyut.213@m.kyushu-u.ac.jp
}

\begin{abstract}
A 2^{3}$ factorial experimental design was used in order to evaluate the preeminent culture contribution variables initial concentration of nitrogen, cultivation time, and inoculum concentration to increase the biomass concentration, protein and fatty acid extraction of Spirulina platensis. Cultivation time is the most contributing factor for the maximum growth of biomass concentration, and harnessing of protein content, but interaction of cultivation time and inoculum concentration for fatty acid extraction. This study illustrates that maximum biomass concentration occurred at initial nitrogen concentration level $0.015 \mathrm{M}$, cultivation time of 20 days and inoculum concentration of $0.1 \mathrm{~g} / \mathrm{l}$.
\end{abstract}

Keywords: Factorial, fatty acid, protein, Spirulina

\section{INTRODUCTION}

Attention of the microalgae and cyanobacteria has been increased recently due to their enormous high-value goods such as high amount of protein, lipids, fatty acid $[1,2]$, pigments, coloring agents, vitamin, and essential minerals [3, 4]. Microalgae compared with other plants have advantages such as no need to arable land for higher productivities [5], produces in the fresh water, saline water, and wastewater $[6,7]$.

Spirulina platensis is a photosynthetic cyanobacteria grows in subtropical and tropical areas of water [8]. Indigenous people of Africa harvested Spirulina from Chad lake as a resource of nourishment [9]. Since 1970s, Spirulina has been cultivated commercially as an additive value of food supplement due to its high yields. Extricates of Spirulina have been stated to have numerous therapeutic effects, counting cholesterol diminishment, anti-cancer, anti-viral and antioxidant impacts $[10,11]$.

Different factors such as initial inoculum concentration, availability of nutrients [12], $\mathrm{pH}$, salinity [13], light intensity, magnetic field [14], temperature, agitation speed [15, 16] and duration of the cultivation [17] directly affect the algae growth and harnessing the content of protein, pigments and valuable fatty acids. Spirulina biomass production are influenced by various factors such as initial inoculum concentration, initial concentration of nitrogen, light irradiance, $\mathrm{pH}$ and cultivation length. The purpose of the research was to examine the effect of variables cultivation length (days), initial concentration of nitrogen $(\mathrm{M})$, and inoculum concentration (g/l) on the growth of (i) biomass concentration, (ii) harnessing the amount of protein, and (iii) fatty acid extraction.

\section{METHODS}

Full factorial design is employed for the growth of Spirulina sp. in this study. Maximum and minimum values are considered regarding the primary experiments
$[18,19]$. This study analyzes the biomass concentration, percentage of protein collection and percentage of fatty acid extraction.

Table 1. levels of variables in the full factorial design

\begin{tabular}{lccc}
\hline \multirow{2}{*}{ Variables (units) } & \multirow{2}{*}{ Symbol } & \multicolumn{2}{c}{ Levels } \\
\cline { 3 - 4 } & & Max. & Min. \\
\hline Initial Concentration of & $\mathrm{A}$ & 0.030 & 0.015 \\
nitrogen (M) & & & \\
Cultivation length (days) & $\mathrm{B}$ & 20 & 15 \\
Inoculum concentration & $\mathrm{C}$ & 0.2 & 0.1 \\
$(\mathrm{~g} / \mathrm{l})$ & & & \\
\hline
\end{tabular}

\subsection{Design of experiments for $2^{3}$ Factorial}

A full factorial design demonstrates to assessment of all eight possible coefficients. A $2^{3}$ factorial design with maximum and minimum levels and three variables was functioned using MATLAB and Minitab to observe the factors for biomass concentration, protein and fatty acid extraction. Let, $\mathrm{A}, \mathrm{B}$ and $\mathrm{C}$ are three variables at two levels $\mathrm{a}_{0}, \mathrm{a}_{1} ; \mathrm{b}_{0}, \mathrm{~b}_{1} ; \mathrm{c}_{0}, \mathrm{c}_{1}$, respectively. In full factorial methods consists of three main effects, three two-way interaction effects, and a three-way factor interaction and a constant term.

The general possible variable combinations can be written as:

$\begin{array}{llllll}(1) & (\mathrm{a}) & (\mathrm{b}) & (\mathrm{c}) & (\mathrm{ab}) & (\mathrm{ac}) \\ \mathrm{a}_{0} \mathrm{~b}_{0} \mathrm{c}_{0} & \mathrm{a}_{1} \mathrm{~b}_{0} \mathrm{c}_{0} & \mathrm{a}_{0} \mathrm{~b}_{1} \mathrm{c}_{0} & \mathrm{a}_{0} \mathrm{~b}_{0} \mathrm{c}_{1} & \mathrm{a}_{1} \mathrm{~b}_{1} \mathrm{c}_{0} & \mathrm{a}_{1} \mathrm{~b}_{0} \mathrm{c}_{1} \\ & & & & & \\ (\mathrm{bc}) & (\mathrm{abc}) & & & & \\ \mathrm{a}_{0} \mathrm{~b}_{1} \mathrm{c}_{1} & \mathrm{a}_{1} \mathrm{~b}_{1} \mathrm{c}_{1} & & & & \end{array}$

Furthermore, the standard statistical test (ANOVA, Ftest, t-test, etc.) was used in this this study whether the variables are significant or not. 


\section{RESULTS AND DISCUSSION}

In this study, a $2^{3}$ factorial experimental technique was assessed to find the consequences of the variables cultivation length (days), initial concentration of nitrogen $(\mathrm{M})$, and inoculum concentration and their effects. The biomass concentration, protein and fatty acid extraction from the cultivation of Spirulina platensis.

3.1 Normal plot of the effect of variables on biomass concentration, protein and fatty acid extraction

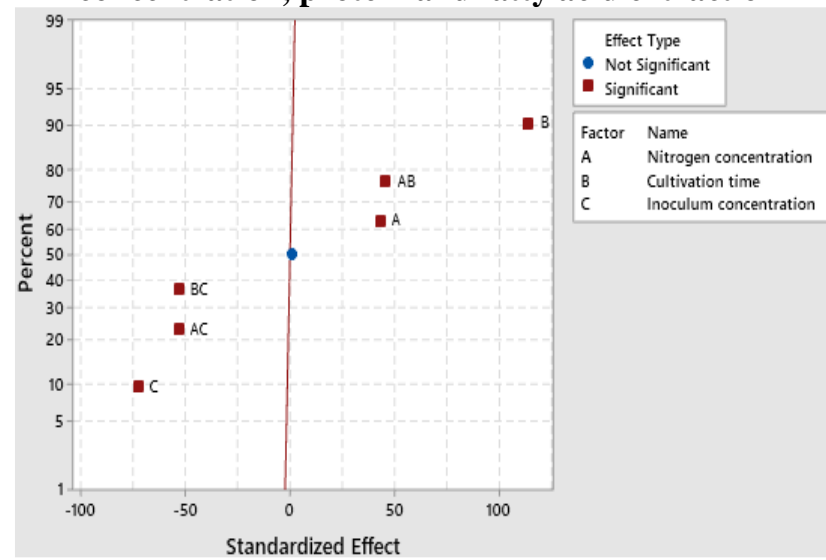

Fig 1 (a). Normal plot for biomass concentration

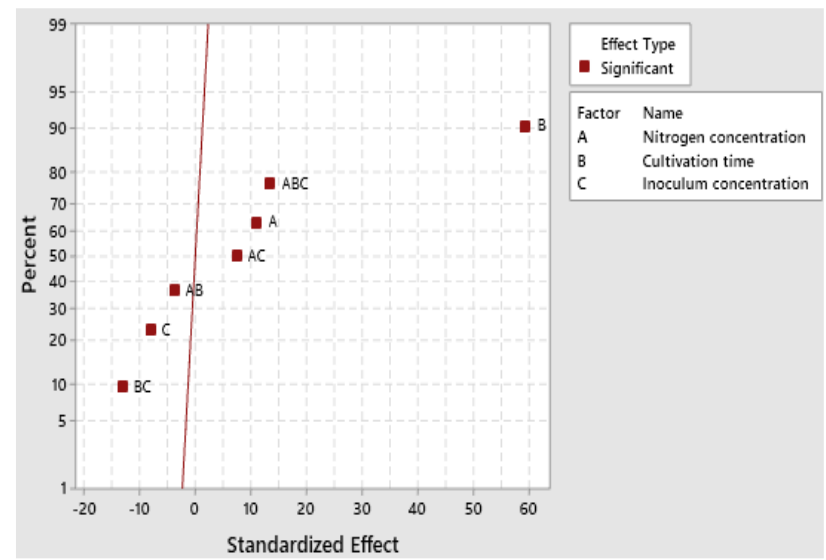

Fig 1 (b): Normal plot for protein extraction

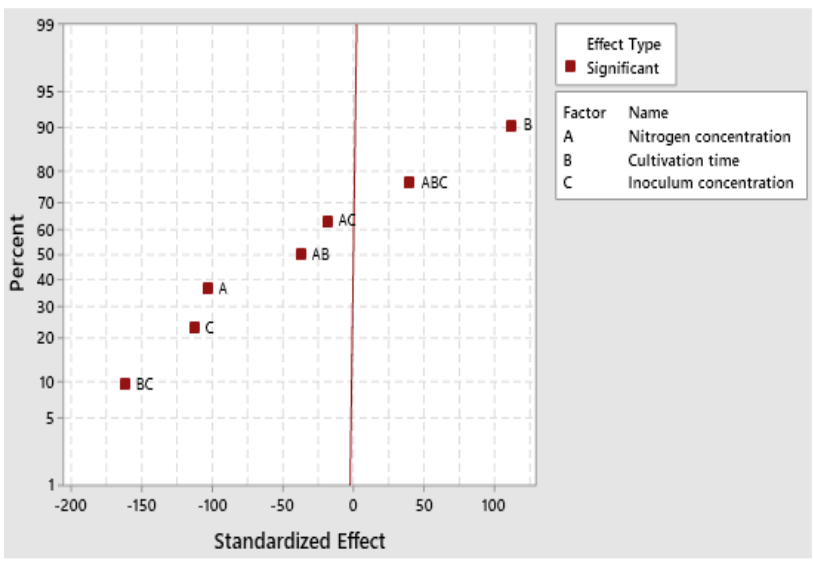

Fig 1 (c): Normal plot for fatty acid extraction

The normal plot indicated for production of biomass, harnessing of protein and fatty acid from Spirulina $s p$. From fig. 1 (a), 1 (b) and 1 (c), we observed that cultivation time is the utmost significant for biomass production and protein extract whereas inoculum concentration and cultivation period is the most significant for fatty acid exploiting from Spirulina $s p$. Main effects and interaction of the variables is suitable to evaluate the importance and significant. Furthermore, the interaction effect $\mathrm{ABC}$ (Initial nitrogen concentration, cultivation time, and initial inoculum concentration) are not statistically significant which shown in fig 1(a).

\subsection{Main effect and interaction of variables on biomass concentration, protein and fatty acid extraction}

Interaction and main influences for each of the variables in the optimization method was utilized to identify the mean differences of the yield factors. Fig 2(a), and 2(b) describes an affirmative relation between the biomass concentration, and protein content and each of the factors of nitrogen concentration and cultivation time.

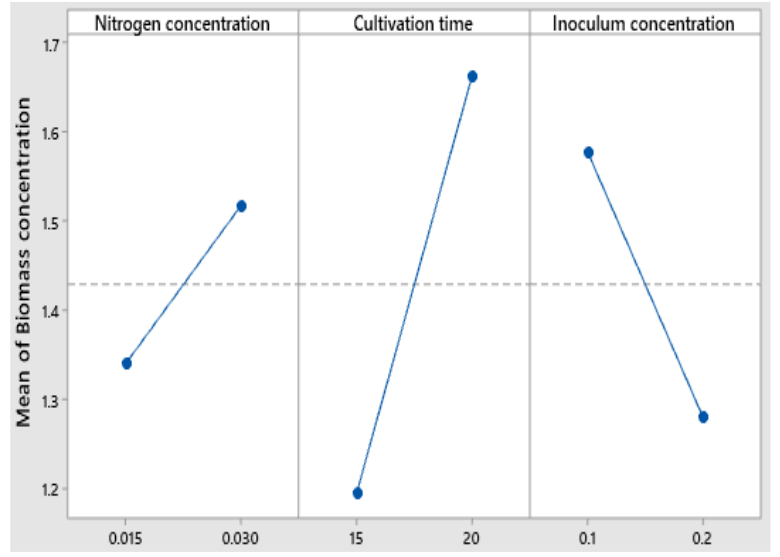

Fig 2(a). Main effect of biomass concentration for the variables

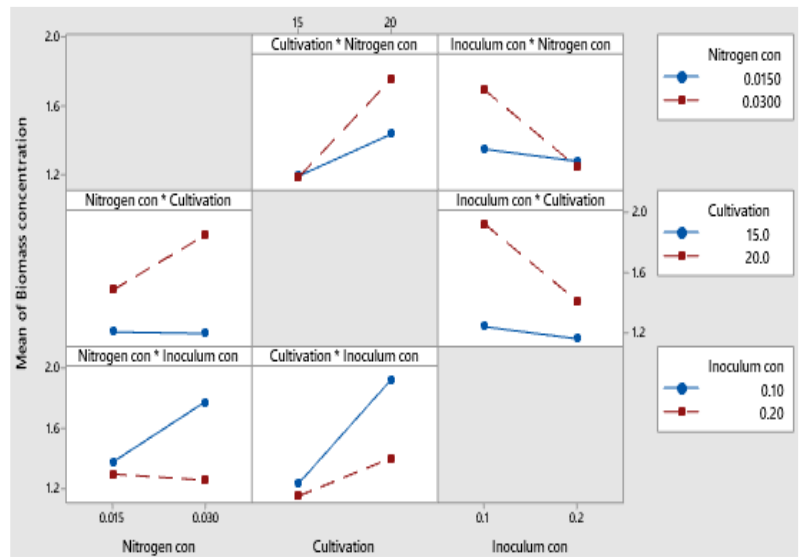

Fig 2(b): Interaction effect of biomass concentration for the variables

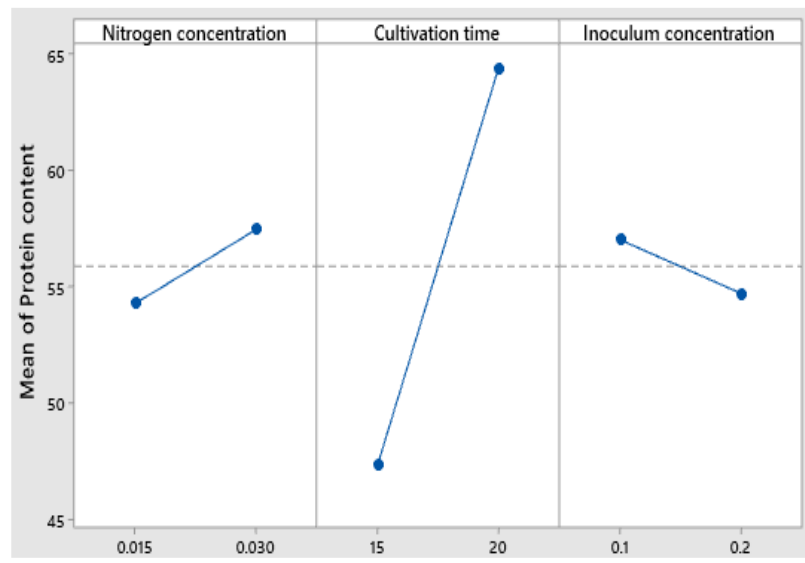

Fig 2(c). Main effect of protein extraction for the variables 


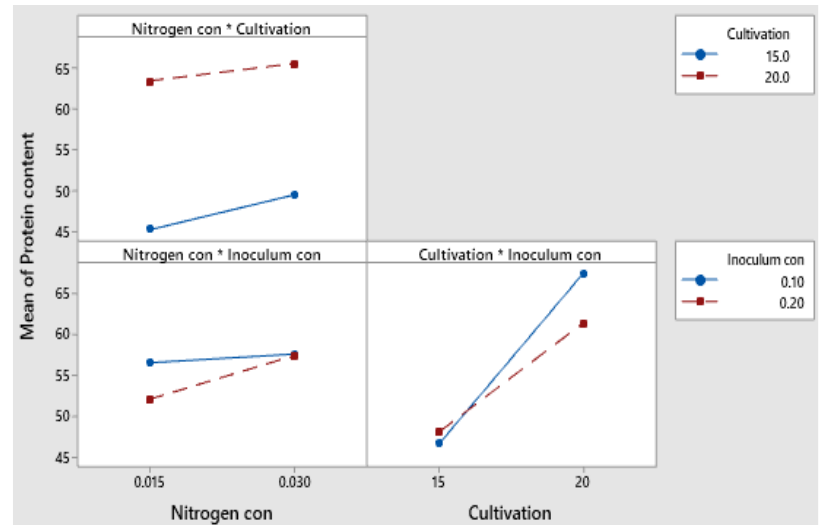

Fig 2(d): Interaction effect of protein extraction for the variables

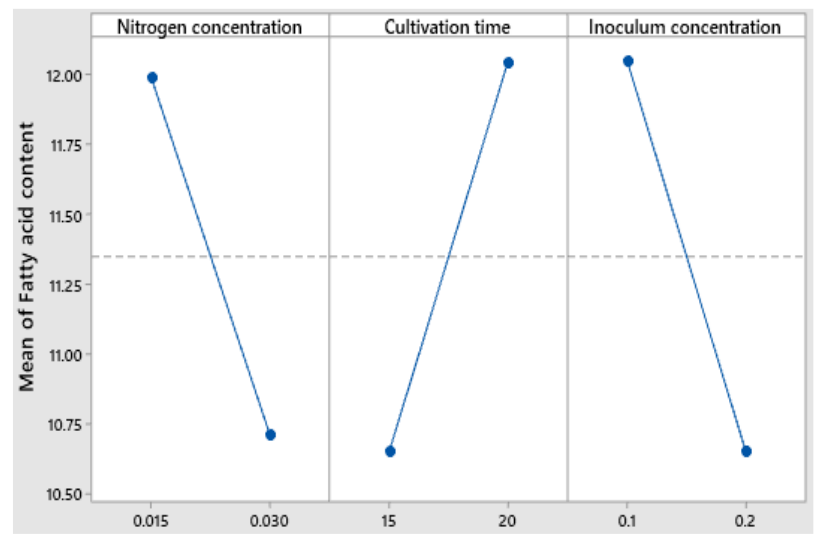

Fig 2 (e). Main effect of fatty acid concentration for the variables

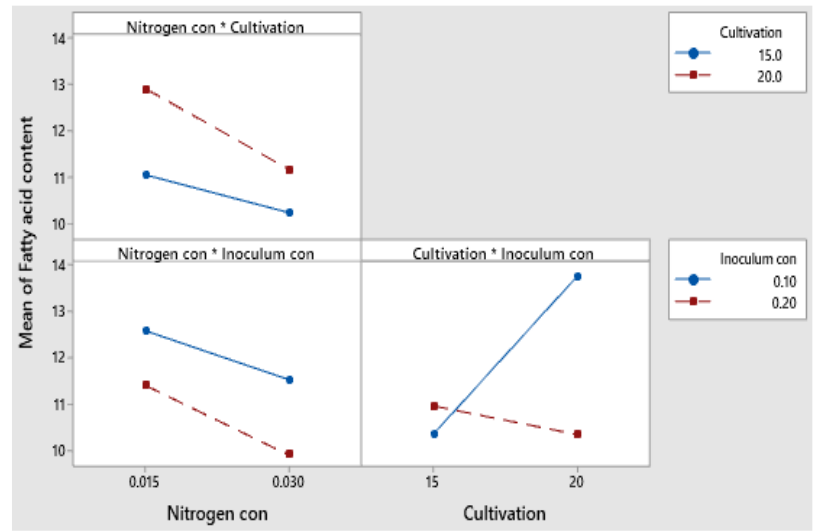

Fig 2(f): Interaction effect of fatty acid concentration for the variables

Fig 2(c) illustrates a negative relationship among nitrogen concentration and fatty acid extraction. It is observed from fig. 2(b), 2(d) that, interaction effect between nitrogen concentration and cultivation time, nitrogen concentration and inoculum concentration, and cultivation time and inoculum concentration has positive significant effect for biomass production, but nitrogen concentration and cultivation time has no interaction effect for protein content, that means they are independent. From fig 2(f), it is remarked that nitrogen concentration and cultivation time, and inoculum concentration and nitrogen concentration have no interaction effects for harnessing valuable fatty acid.

\subsection{Cube charts for the biomass concentration, protein and fatty acid extraction}

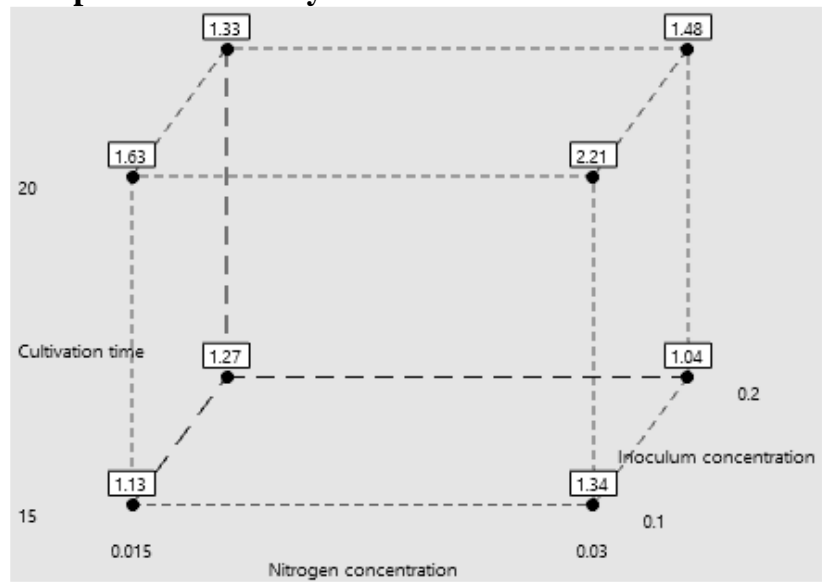

Fig 3(a). Cube plot of biomass concentration

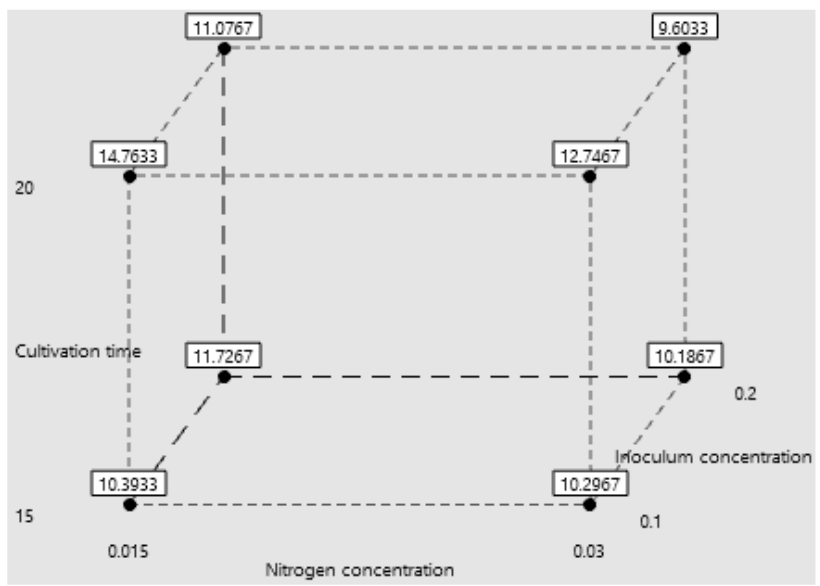

Fig 3(a). Cube plot of fatty acid content

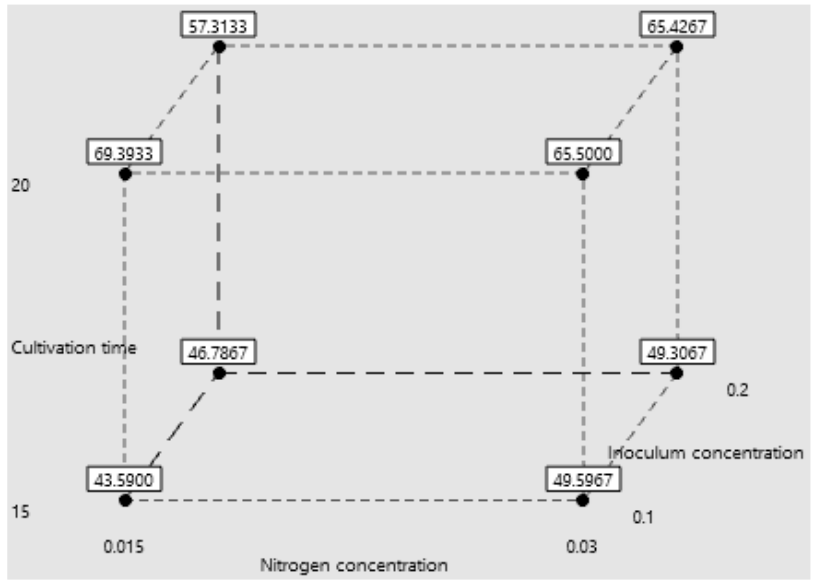

Fig 3(a). Cube plot of protein content

The cubical charts represented in fig 3(a), 3(b) and 3(c) provides the optimized biomass concentration, fatty acid and protein content extraction at a distinct level of variables. From fig 3(a), it is stated that biomass concentration is the highest $(2.21 \mathrm{~g} / \mathrm{l})$ at nitrogen concentration level $0.03 \mathrm{M}$, where cultivation time is 20 days, and initial inoculum concentration $0.2 \mathrm{~g} / \mathrm{l}$. But it is not the same condition for fatty acid, and protein content extraction. 


\subsection{Analysis of variance for the biomass concentration, protein and fatty acid extraction}

Optimized biomass concentration, fatty acid and protein content at distinct levels of variables recognize the most important factors and their interaction effects. Analysis of variance (ANOVA) was applied to test the mean effects of different variables are equal or not.

Table 2. represented the degrees of freedom (DF), adjusted sum of squares (Adj SS), adjusted mean sum of squares (Adj MS), P-values, and F values, and the effect of variables is statistically significant at 1 percentage level if P-value less than 0.01. From table 2, it is observed that all linear and two-way interaction effects are statistically significant but three-way interactions is not significant for production of biomass. It is shown that the sum of squares values of cultivation length (B) is the highest (1.3114). For two-way interaction effects, AC (nitrogen concentration and inoculum concentration), and $\mathrm{BC}$ (cultivation time and inoculum concentration) has the same effects on the product of biomass concentration. $\mathrm{AB}$ (nitrogen concentration and cultivation time) have the approximately similar effect. Similar analysis was done for the extraction of fatty acid and protein content from the Spirulina biomass. Nonetheless, in this study, it is not shown.

Table 2: Parameters optimization for the production biomass concentration by using ANOVA technique

\begin{tabular}{|c|c|c|}
\hline Source & DF Adj SS & \\
\hline Model & 72.81006 & 0.40144 \\
\hline Linear & 32.03141 & 0.67714 \\
\hline Nitrogen concentration & 10.18904 & +0.1890 \\
\hline Cultivation time & 11.31134 & +1.3113 \\
\hline Inoculum concentration & 10.53104 & +0.5310 \\
\hline 2-Way Interactions & 30.77861 & 0.259 \\
\hline $\begin{array}{l}\text { Nitrogen concentration*Cultivation } \\
\text { time }\end{array}$ & 10.21094 & 0.210 \\
\hline $\begin{array}{l}\text { Nitrogen concentration*Inoculum } \\
\text { concentration }\end{array}$ & 10.28384 & 0.283 \\
\hline $\begin{array}{l}\text { Cultivation time*Inoculum } \\
\text { concentration }\end{array}$ & 10.28384 & 0.283 \\
\hline 3-Way Interactions & 10.00004 & +0.0000 \\
\hline $\begin{array}{l}\text { Nitrogen concentration*Cultivation } \\
\text { time*Inoculum concentration }\end{array}$ & 10.00004 & +0.000 \\
\hline Error & 160.00160 & 0.000 \\
\hline Total & 232.81166 & \\
\hline Source & F-Value & P-Value \\
\hline Model & 4014.38 & 0.000 \\
\hline Linear & 6771.38 & 0.000 \\
\hline Nitrogen concentration & 1890.38 & 0.000 \\
\hline Cultivation time & 13113.38 & 0.000 \\
\hline Inoculum concentration & 5310.38 & 0.000 \\
\hline 2-Way Interactions & 2595.38 & 0.000 \\
\hline $\begin{array}{l}\text { Nitrogen concentration*Cultivation } \\
\text { time }\end{array}$ & 2109.38 & 0.00 \\
\hline $\begin{array}{l}\text { Nitrogen concentration*Inoculum } \\
\text { concentration }\end{array}$ & 2838.38 & 0.00 \\
\hline $\begin{array}{l}\text { Cultivation time*Inoculum } \\
\text { concentration }\end{array}$ & 2838.38 & 0.000 \\
\hline 3-Way Interactions & 0.37 & 0.549 \\
\hline Nitrogen concentration*Cultivation & 0.37 & 0.54 \\
\hline
\end{tabular}
time* Inoculum concentration

R-square

R-square(adj) 99.94\%

$99.92 \%$
3.5 Surface plot and contour plot for the biomass concentration, protein and fatty acid extraction

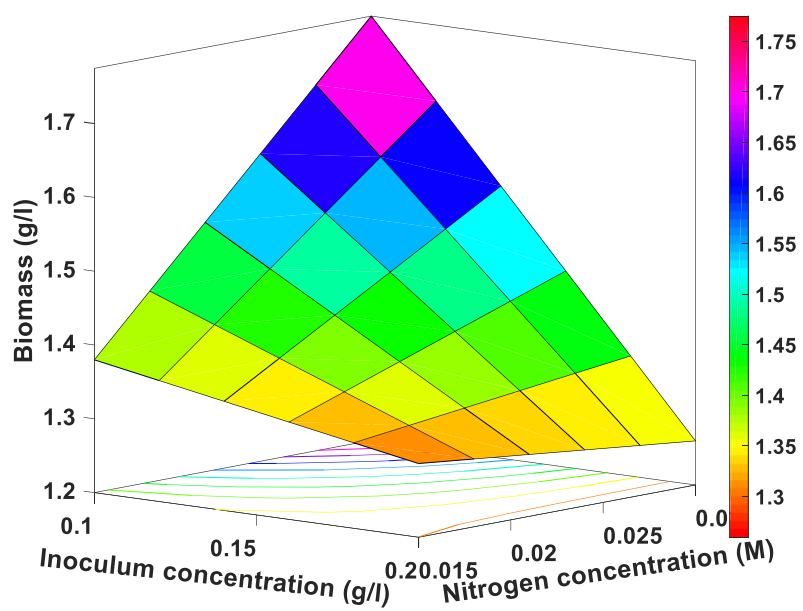

Fig 4(a). Surface and contour plot of inoculum concentration and nitrogen concentration for biomass concentration

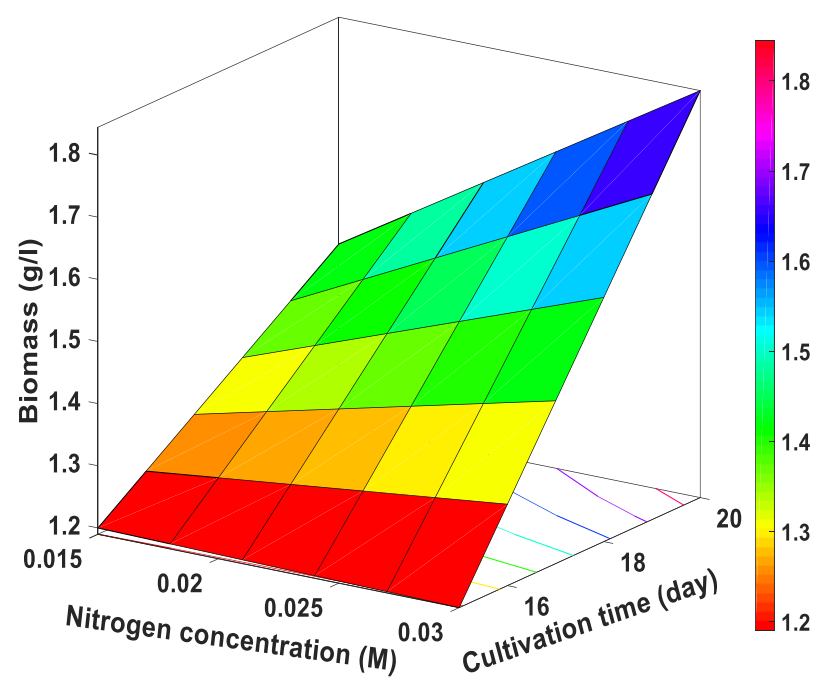

Fig 4(b). Surface and contour plot of cultivation time and nitrogen concentration for biomass concentration

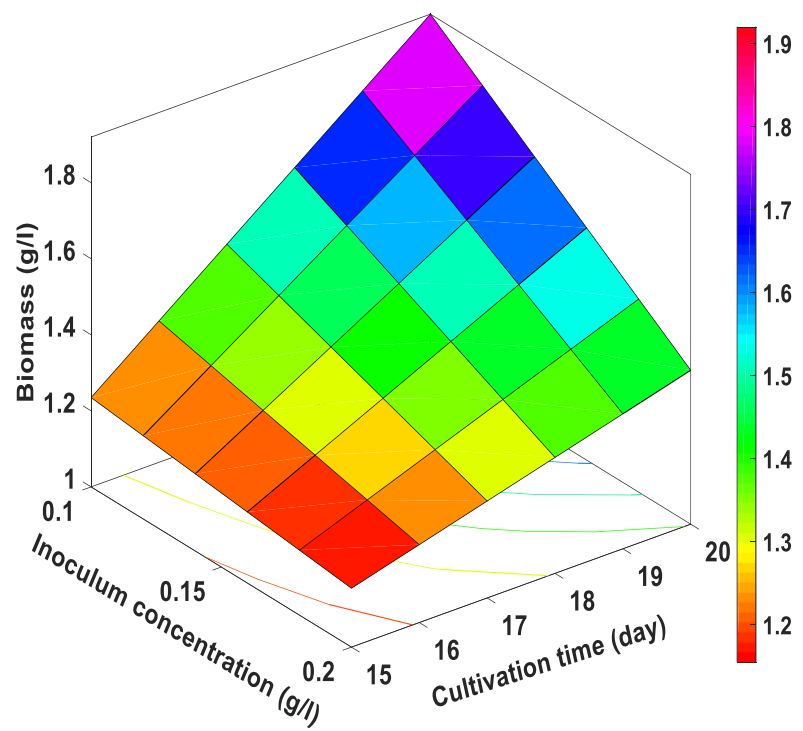

Fig 4(c). Surface and contour plot of cultivation time and inoculum concentration for biomass concentration 


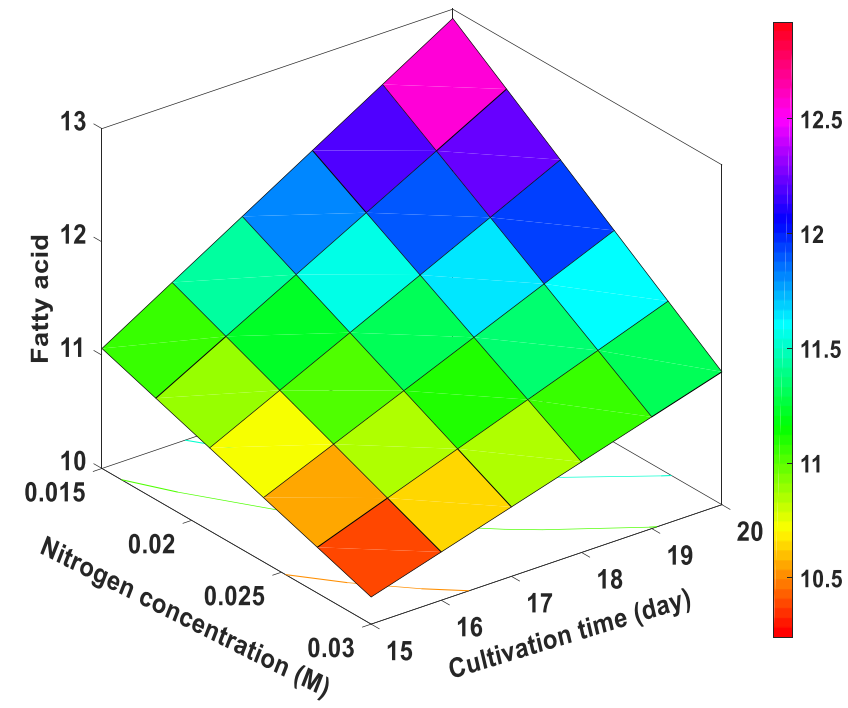

Fig 5(a). Surface and contour plot of cultivation time and nitrogen concentration for fatty acid extraction

In this study, surface plot and counter plot describes the relationship among the dependent (biomass concentration, fatty acid, and protein content) and independent (initial nitrogen concentration, cultivation time, and initial inoculum concentration) factors. In contour plots, $\mathrm{x}$ and $\mathrm{y}$-axis represents the predictor variables and $\mathrm{z}$-axis represent response variable. It is the best way to explain a 3-dimensional surface on a 2dimensional plane. Surface plots exhibit a relationship among the predictor variables (x, and y-axis) and the response variable (z-axis). In figure 4(a), 4 (b), and 4(c) shows the surface and contour plot for biomass concentration in the same set of axes. Biomass concentration is more than $1.75 \mathrm{~g} / \mathrm{l}$ if inoculum concentration at maximum level $(0.20 \mathrm{~g} / \mathrm{l})$ and nitrogen concentration at minimum level $(0.015 \mathrm{M})$.

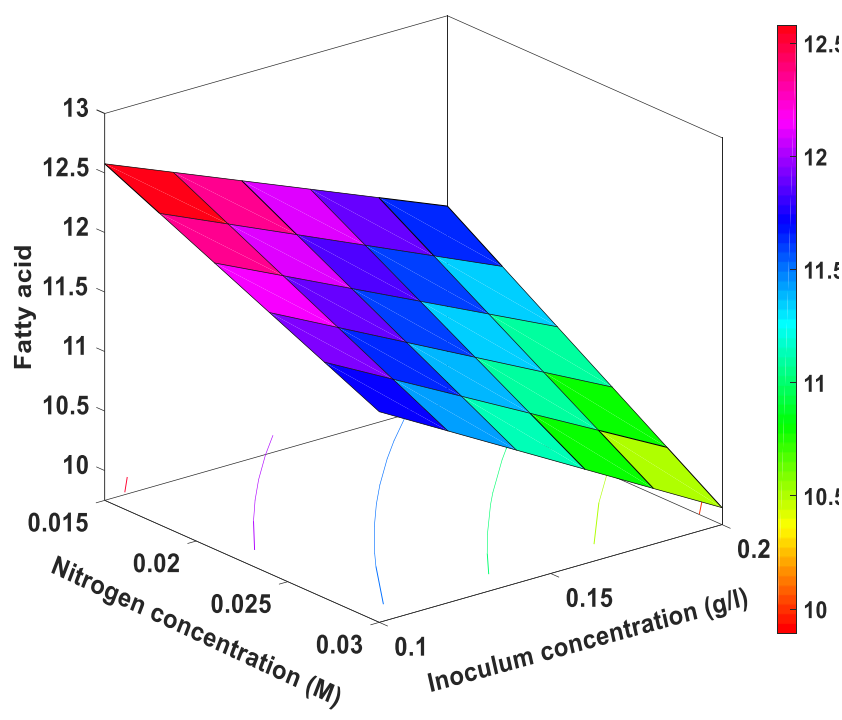

Fig 5(b). Surface and contour plot of inoculum concentration and nitrogen concentration for fatty acid extraction

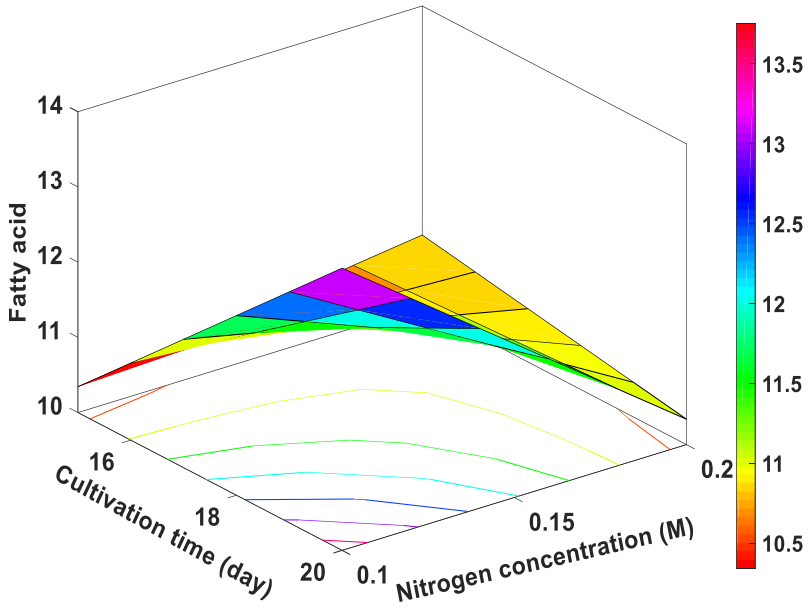

Fig 5(c). Surface and contour plot of cultivation time and nitrogen concentration for fatty acid extraction

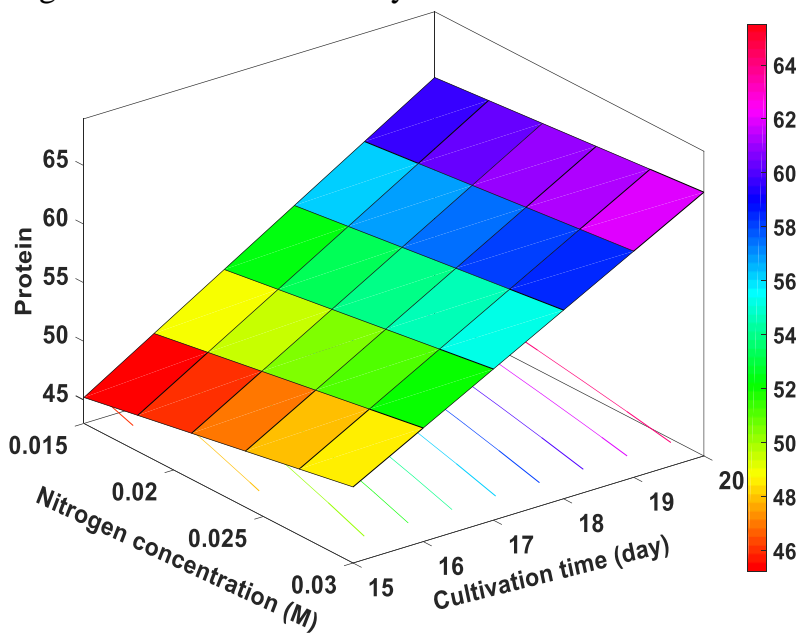

Fig 6(a). Surface and contour plot of cultivation time and nitrogen concentration for protein content

The response surfaces 5(a), 5(b), and 5(c) shows the effect of the variables studied on the fatty acid extraction, and 6(a), 6(b), and 6(d) represents the effect of the factors on the harnessing of protein content. Extraction of fatty acid upsurges when cultivation time increased from 15 to 20 days and Nitrogen concentration decreased from 0.2 to $0.1(\mathrm{M})$. The protein amount increases when the cultivation time and nitrogen concentration increased from 15 to 20 days and 0.015 to $0.03 \mathrm{M}$ respectively.

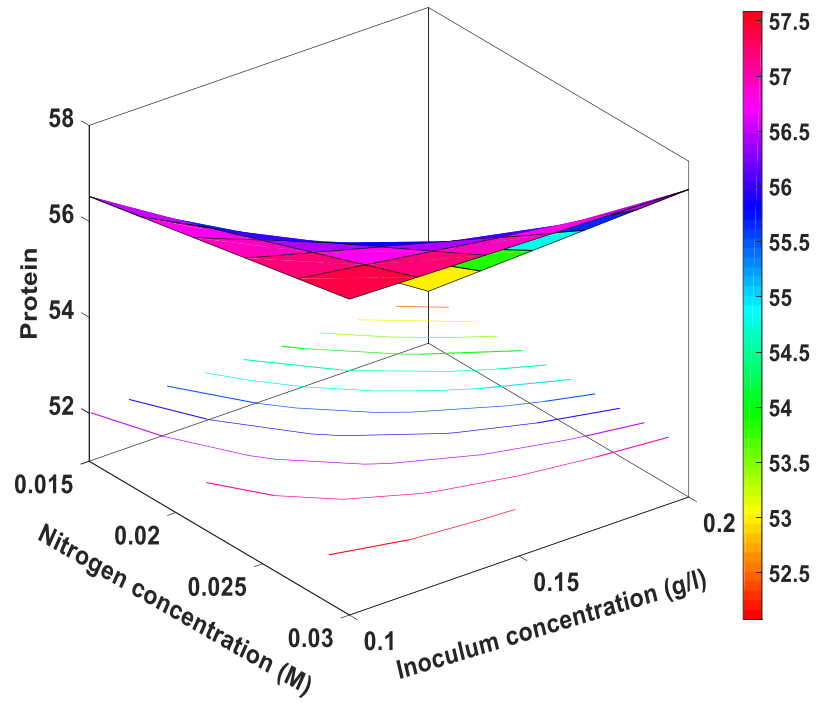

Fig 6(b). Surface and contour plot of inoculum concentration and nitrogen concentration for protein content 


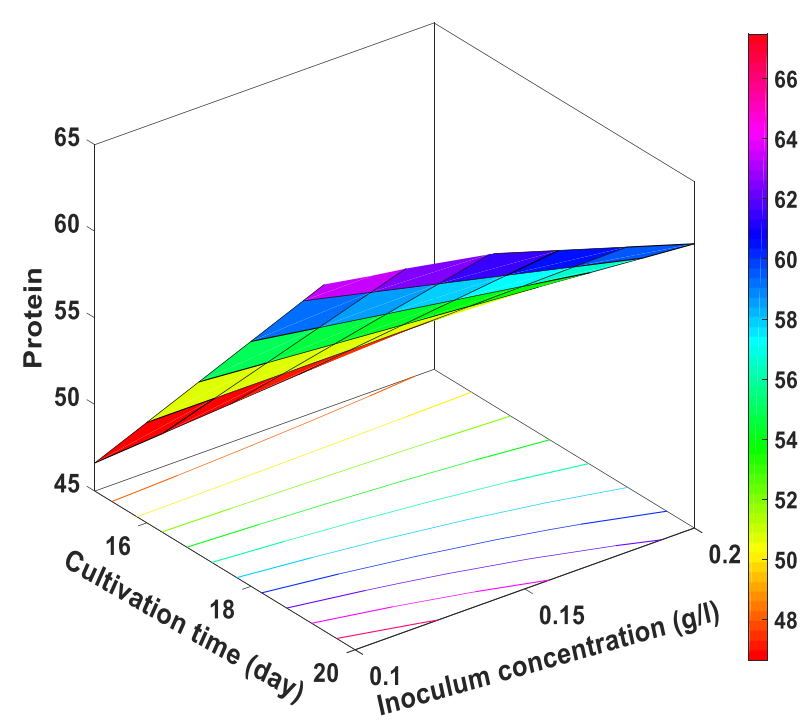

Fig 6(c). Surface and contour plot of cultivation time and inoculum concentration for protein content

\section{CONCLUSIONS}

The $2^{3}$ full factorial technique was analyzed depend on the three variables at two points used to reveal the main effects of initial nitrogen concentration, cultivation time, and inoculum concentration, and their relations. Cultivation time was obtained to be the main potential variable for this amount of biomass concentration followed by inoculum concentration and interaction between nitrogen concentration and inoculum concentration. For protein content extraction the most significant variable was cultivation time followed by the interaction among three variables. It is observed for harnessing fatty acid, interaction between cultivation time and inoculum concentration is the most significant factors followed by inoculum concentration.

\section{REFERENCES}

[1] P. Spolaore, C.C. Jonnnnis, E. Duran, A. Isabert, Commercial applications of microalgae, Society of Biotechnology of Japan, 101, 87-96, 2006.

[2] Y. Chisti, Biodiesel from Microalgae (Research review paper), Biotechnology Advances 25 294-306, 2007.

[3] S. Al-Thawadi, Public perception of algal consumption as an alternative food in the kingdom of Bahrain, Aran journal of basic and applied sciences, 25, 1, 1-12, 2018.

[4] M. Vigani, C. Parisi, E.R. Cerezo, M.J. Barbosa, L. Sijsma, M. ploeg, C. Enzing, Food and feed products from microalgae: Market opportunities and challenges for the EU, Trends in food science and technology, 42, 81-92, 2015.

[5] M. Khan, J.H. Shin, J.D. Kim, The promising future of microalgae: current status, challenges, and optimization of a sustainable and renewable industry for biofuels, feed, and other products. Microbial cell factories, 17, 17-36, 2018.

[6] L. Pane, C. Solisio, A. Lodi, G.L. Mariottini, A. Converti, Effect of extracts from Spirulina platensis bioaccumulating cadmium and zinc on L929 cells, Ecotoxicology and environmental and safety, 70 (1) 121-126, 2008.
[7] A. Lodi, L. Binaghi, D.D. Faveri, J.C.M. Carvalho, A. Converti, Chromium (III) removal by Spirulina platensis biomass. Chemical engineering journal, 136, 151-155, 2008.

[8] H. Kemka Ogbonda, R.E. Aminigo, G.O. Abu, Influence of temperature and $\mathrm{pH}$ on biomass production and protein biosynthesis in a putative Spirulina sp., Bioresource technology 98 (2207-2211) 2007.

[9] A. Vonshak, Spirulina platensis (Arthrospira): Physiology, Cell Biology and Biotechnology. Taylor and Francis, London, 1997.

[10] P.D. Karkos, S.C. Leong, C.D. Karkos, N. Sivaji, D.A. Assimakopoulos, Spirulina in clinical practice: Evidence- based human applications (Review article), Evidence based complementary and alternative medicine, 2011, 531053, 2011.

[11] C. Yi-Hsiang, C. Gi-Kung, K.S. Ming, H.S. Yu, H.I. Chen, L.Y. Lun, S.S. Ru, Well tolerated Spirulina extract inhibits influenza virus replication and reduces virus-induced mortality, Scientific reports, 6 24253, 2016.

[12] A. Celekli, M. Yavuzatmaca, Predictive modeling of biomass production by Spirulina platensis as function of nitrate and $\mathrm{NaCl}$ concentrations, Bioresource technology, 100, 1847-1851, 2009.

[13] A. Juneja, R.M. Ceballos, G.S. Murthy, Effects of environmental factors and nutrient availability on the biochemical composition of algae for biofuels production: A review. Energies, 6, 4607-4638, 2013.

[14] A. Carolina Ferreira Piazzi, M.C. Veiga, L.O. Santos, J.A.V. Costa, R.C. Kuhn, N.P.G. Salau, Modeling the growth of microalgae Spirulina $s p$. With application of illuminance and magnetic field, Journal of Chem. Technol. Biotechnology, 94, 1770-1776, 2019.

[15] E. Imamoglu, M.C. Dalay, F.V. Sukan, Influences of different stress media and highlight intensities on accumulation of astaxanthin in the green alga Haematococcus pluvialis. New biotechnology, 26 (34), 199-204, 2009.

[16] I. Senaha, K. Nagamatsu, D. Yamashiro, Y. Watabe, B.B. Saha, Development of high-speed and largescale culture technology of marine algae using seawater with high concentrations of dissolved carbon dioxide, Heat transfer engineering, 37, 625632, 2015.

[17] R. Ramaraj, D.D.Tsai, P.H. Chen, Detention time study of algal biomass production with natural water medium, Chiang Mai journal of science, 42(3), 549$559,2015$.

[18] J. Alberto Vieira costa, G.A. Linde, D.I.P. Atala, G.M. Mibielli, R.T. Kruger, Modeling of growth conditions for cyanobacterium Spirulina platensis in microcosms, World J. of Microbiology and Biotechnology. 16: 15-18, 2000.

[19] S. Wen-qing, S. Dong Li, G. Li, W. Wang, Q. Chen, Y. Li, X. Ling, Investigation of main factors affecting the growth rate of Spirulina, Optik 127, 16, 66886694, 2016. 